\title{
THE USE OF LEVOCETIRIZINE IN THE TREATMENT OF ITCHING DERMATITIS
}

\section{Fedosenko Oleksandr ${ }^{1}$}

DOI: https://doi.org/10.30525/978-9934-571-89-3_86

The development of a treatment strategy for a number of allergic diseases has historically been associated with identifying the role of histamine in the mechanism for the development of allergic symptoms. There are various methods of suppressing the activity of histamine in the body. For example, corticosteroids. Histamine receptor blockers, anti-leukotriene drugs prevent histamine from acting on target cells.

Itching dermatitis include contact dermatitis, eczema and atopic dermatitis. The clinical manifestations of these diseases have a different picture, but the underlying pathogenesis mechanisms are similar. Previously used the term - "neurodermatosis". Now this name is rarely used, although it emphasizes the role of changes in the nervous system and its effect on the occurrence and course of the disease [1].

Itching is one of the leading symptoms of most allergic dermatitis. Combing the surface of the skin leads to increased production and release of pro-inflammatory

${ }^{1}$ Donetsk National Medical University, Ukraine 
cytokines, which can increase itching and trigger a vicious cycle involving these phenomena [2].

One of the causes of itch is histamine, whiles other mechanisms, central and peripheral, and is still being studied. It is known that serotonin, proteases, such as kallikrein, papain, and peptides - bradykinin, prostaglandins, leukotrienes and Eicosanoids have an itching effect [3].

The problem of treating itching dermatitis remains highly relevant. In the treatment of diseases of this group, the use of antihistamine drugs is the "gold standard". Antihistamine activity is based on the ability to remove the peripheral effects of the mediator of allergy - histamine, and it is in those tissues that are mainly involved in the clinical manifestations of allergy. On the part of the skin, typical manifestations of the action of histamine are a feeling of itching and a blistering - hyperemic reaction. Antihistamines prevent the action of histamine by blocking its $\mathrm{H} 1$ receptors. The rapid manifestation of the effect and increase the safety of their medical use - the necessary characteristics of modern anti-histamine drugs [4].

However, the majority of these drugs give a number of adverse side effects, most often in the form of drowsiness, less often - the development of addiction.

That is why there is an increased interest in antihistamine drugs of the new generation, which have high therapeutic efficacy, have a quick and long-lasting effect and do not affect the ability to work, concentration, and coordination of movements.

The drug that meets these characteristics is levocetirizine. This is a new antihistamine and anti allergic drug of the third generation. Levocetirizine blocks H1 - histamine receptors. It prevents development and facilitates the course of allergic reactions, has anti exudative, anti itching and anti inflammatory effects.

High bioavailability, low metabolism, lack of interaction with other drugs - these pharmacokinetic features make Levocetirizine available for the treatment of allergies in all patients. Also, this drug is suitable for the treatment of persons suffering from diseases of the liver and heart, as it does not affect intra cardiac conduction. Levocetirizine begins to act during the first hour in all groups of patients. Proved good tolerability with prolonged use while maintaining high efficiency.

In Ukraine, levocetirizine is used to treat the symptoms of allergic rhinitis and allergic conjunctivitis, such as itching, sneezing, rhino rhea, lacrimation, conjunctively hyperemia; hay fever (pollinosis), urticaria, including chronic idiopathic urticaria, angioedema; other allergic dermatitis, accompanied by itching and rash.

Levocetirizine is contraindicated in case of hypersensitivity to any of the components of the drug, in severe form of chronic renal failure (CRF).It is also not recommended to prescribe it to women during pregnancy and lactation.

The drug is easy to use: 1 tablet ( $5 \mathrm{mg}$ of levocetirizine) per day, regardless of the meal.Thus, levocetirizine has a high therapeutic efficacy in the treatment of widespread itching dermatitis (atopic dermatitis, chronic urticaria), contributes to the disappearance of itching, rapid resolution of lesions and prevents the appearance of new ones. Levocetirizine is distinguished by a high degree of safety, the absence of pronounced side effects and good tolerance, and can also be recommended for use in clinical practice. 


\section{References:}

1. Sergeev Yu.V. (2006). Atopicheskiy dermatit [Atopic Dermatitis]. Moscow: Meditsina dlya vsekh.

2. Novikova V.I., Novikova N.D. (2001). Klinicheskaya effektivnost' kestina pri lechenii allergicheskikh zabolevaniy [Clinical efficacy of kestin in the treatment of allergic diseases]. Immunologiya. Allergologiya. Infektologiya.[ Immunology. Allergology. Infectology]. Moscow: Obshcherossiyskaya obshchestvennaya organizatsiya Obshchestvennaya natsional'naya akademiya mikologii, pp. 58-60.

3. Hanifin JM, Rajka G. (1990). Diagnostic features of atopic dermatitis. Acta Derm Venereal Suppl. Stockholm, pp. 44-47.

4. Gispert J, Antanijan R., Barbanoj M. (2000). Comparative assessment of antiH1 activity. Poster presentation at EAACI Congress. Lisbon. 